\title{
An alginate-layer technique for culture of Brassica oleracea L. protoplasts
}

\author{
Agnieszka Kiełkowska • Adela Adamus
}

Received: 24 October 2011 / Accepted: 3 February 2012 / Published online: 30 March 2012 / Editor: J. Forster

(C) The Author(s) 2012. This article is published with open access at Springerlink.com

\begin{abstract}
Ten accessions belonging to the Brassica oleracea subspecies alba and rubra, and to B. oleracea var. sabauda were used in this study. Protoplasts were isolated from leaves and hypocotyls of in vitro grown plants. The influence of selected factors on the yield, viability, and mitotic activity of protoplasts immobilized in calcium alginate layers was investigated. The efficiency of protoplast isolation from hypocotyls was lower $\left(0.7 \pm 0.1 \times 10^{6} \mathrm{ml}^{-1}\right)$ than for protoplasts isolated from leaf mesophyll tissue $(2 \pm$ $\left.0.1 \times 10^{6} \mathrm{ml}^{-1}\right)$. High $(70-90 \%)$ viabilities of immobilized protoplasts were recorded, independent of the explant sources. The highest proportion of protoplasts undergoing divisions was noted for cv. Reball F1, both from mesophyll $(29.8 \pm 2.2 \%)$ and hypocotyl $(17.5 \pm 0.3 \%)$ tissues. Developed colonies of callus tissue were subjected to regeneration and as a result plants from six accessions were obtained.
\end{abstract}

Keywords Brassica alba, rubra, sabauda $\cdot$ Calcium alginate $\cdot$ Hypocotyl $\cdot$ Mesophyll

\section{Introduction}

The economic and agronomic importance of Brassica species is well known, due to their use as vegetable and oil seed crops, and as sources of condiments (Fahleson et al. 1994). Conventional breeding in Brassica spp. has delivered improvements of both quality and yield, but corresponding

\footnotetext{
A. Kiełkowska $(\triangle) \cdot$ A. Adamus

Department of Genetics, Plant Breeding and Seed Science,

University of Agriculture in Krakow,

A1. 29-Listopada 54,

31-425 Krakow, Poland

e-mail: kielkowska@ogr.ar.krakow.pl
}

enhancements of traits such as disease resistance have been restricted by the limited availability of suitable genes in the germplasm pool, and with the problems of transferring of such traits (Radchuk et al. 2002). With the development of techniques for enzymatic isolation of protoplasts and regeneration, a valuable tool for plant genetic manipulation has become available.

Studies of protoplasts isolation in Brassica spp. started in the early 1980s. The majority of available reports on isolation of protoplasts and subsequent somatic fusions with protoplasts from other members of the Brassicaceae family, as well as distant species were focused mainly on oilseed rape (Brassica napus; Yarrow et al. 1990; Hansen and Earle 1994; Heath and Earle 1997; Yamagishi et al. 2002). This species is important for vegetable oil production, and genetic manipulation aimed at modification of the fatty acid composition, and has been targeted for broadening of competitiveness within the market (Wang et al. 2003).

The diploid species Brassica oleracea is highly morphologically variable and includes vegetable crops such as kale, cauliflower, cabbage, Brussels sprouts, and kohlrabi. Protoplast isolation and protoplast-derived plant regeneration protocols have been reported for B. oleracea, and somatic hybridization has been used to transfer genes for resistance to diseases such as Alternaria brassicae from Sinapis alba L. (Hansen and Earle 1997) and Capsella bursa-pastoris (Sigareva and Earle 1999), Xanthomonas campestris pv. campestris resistance from B. napus (Hansen and Earle 1995), and Ervinia carotovora resistance from Brassica rapa (Ren et al. 2000). The cytoplasmic male sterility system has been introduced to $B$. oleracea through asymmetric protoplast fusion (Sigareva and Earle 1997). Positive results, as mentioned above, have been achieved using $B$. oleracea accessions that were selected for high plant regeneration capacity, but the ability to undergo meiotic divisions and 
regenerate shoots remained problematic (Jourdan and Earle 1989; Zhao et al. 1995; Hansen et al. 1999a). Although intensive screening of protoplast culture conditions has been performed, the effects of genotype have still overridden most efforts to improve protocols for plant regeneration from protoplast culture. The major obstacle for commercial application of protoplast fusion in B. oleracea has been the lack of breeding lines with high capacity for plant regeneration from in vitro cultures (Holme et al. 2004).

Protoplasts derived from cell wall digestion with enzyme preparations are highly vacuolated and very fragile, hence being difficult to culture. Immobilization of protoplasts, involving entrapment of cells in a polymerizing matrix, is a relatively easy and cheap method that helps to protect the isolated cells and maintain the culture. Available data suggests that immobilization in a semisolid matrix, such as calcium alginate, allows undisturbed rebuilding of the cell wall, prevents cell agglutination, and promotes completion of mitotic divisions (Hall et al. 1993; Dirks et al. 1996; Dovzhenko et al. 1998; Pati et al. 2005). To our knowledge, immobilization of protoplasts in alginate layers has never been utilized for B. oleracea, and only one report of its use has been made for B. napus, with division frequencies in the 3-5\% range (Dovzhenko 2001).

The objective of this study was to analyze yields, viability, and division frequencies of Brassica oleracea protoplasts embedded in calcium alginate, and to establish in vitro culture conditions for effective shoot regeneration.

\section{Materials and Methods}

Plant material. The following sources of mesophyll protoplasts were used: $B$. oleracea var. capitata $f$. alba cultivars Kamienna Głowa (PlantiCo, Poland), Amager (PNOS, Ożarów Mazowiecki, Poland), Kilaxy F1 (Syngenta Seeds), Benia F1 (POLAN, Poland); B. oleracea var. capitata $f$. rubra cv. Reball F1 (Syngenta Seeds), Rodeo F1 (Nickerson Zwaan, Netherlands); B. oleracea var. sabauda (Savoy cabbage) cv. Vertus F1 (PlantiCo). Seeds of all mentioned cultivars were commercial samples. Mesophyll protoplasts were also isolated from three DH lines (No. 582, 1071, 5071) obtained via microspore embryogenesis from the $B$. oleracea var. capitata f. rubra in the Dept. of Genetics, Plant Breeding and Seed Science in Krakow, Poland. Hypocotyl protoplasts were isolated from cultivars Kamienna Głowa, Kilaxy F1, and Reball F1.

Seeds of all accessions were sterilized in 70\% $(v / v)$ ethanol for $2-3 \mathrm{~min}, 10 \%(w / v)$ chloramine $\mathrm{T}$ (Biochemie Poland, Katowice, Poland) for $20 \mathrm{~min}$, and washed three times with sterile distilled water for $5 \mathrm{~min}$. Seeds were germinated on MS (Murashige and Skoog 1962) medium supplemented with $0.8 \%(w / v)$ agar (Biocorp, Warszawa,
Poland). In order to obtain plantlets with well-developed leaves, seeds were placed in sterile $250 \mathrm{ml}$ glass jars containing $30 \mathrm{ml}$ of MS medium, and kept at $26 \pm 2{ }^{\circ} \mathrm{C}$ under $16 \mathrm{~h}$ photoperiod with light intensity $55 \mu \mathrm{mol} \mathrm{m}^{-2} \mathrm{~s}^{-1}$. Etiolated hypocotyls were obtained from seeds placed in $9 \mathrm{~cm}$ Petri dish with $5 \mathrm{ml}$ of MS medium, kept in the dark at $26 \pm$ $2^{\circ} \mathrm{C}$.

Protoplast isolation and culture. Newly expanded young leaves of 2-, 4-, and 6-wk-old plants, and hypocotyls from 1- to 2-wk-old seedlings were used. In both cases, $1 \mathrm{~g}$ of plant tissue was placed on a glass Petri dish in the presence of $0.5 \mathrm{M}$ mannitol at $\mathrm{pH} 5.8$ (plasmolysis solution), was cut into fine pieces and incubated for $1 \mathrm{~h}$ in the dark at $25^{\circ} \mathrm{C}$. The suspension was then treated with the selected enzyme solution and incubated for $16-18 \mathrm{~h}$ in the dark at $25^{\circ} \mathrm{C}$ with gentle shaking ( $30 \mathrm{rpm})$. For digestion of protoplasts from mesophyll and hypocotyls of tested cultivars, ES enzyme solution consisting of KM (Kao and Michayluk 1975) medium, $0.1 \%(w / v)$ macerozyme R-10 (Duchefa Biochemie, Netherlands), $1.0 \%(w / v)$ cellulase Onozuka R-10 (Duchefa Biochemie), and $0.8 \mathrm{M}$ sucrose $\mathrm{pH} 5.6$ was used. For protoplast isolation from mesophyll of the DH lines, beside ES enzyme solution, ES IV and D solutions were used. The ES IV enzyme solution consisted of $1.0 \%(w / v)$ cellulase Onozuka R-10, 0.1\% (w/v) pectolyase Y-23 (Duchefa Biochemie, NL), 0.6 M mannitol, $20 \mathrm{mM}$ 2-( $N$-morpholino) ethanesulfonic acid (MES; Sigma), $5.0 \mathrm{mM} \mathrm{MgCl} 2 \cdot 6 \mathrm{H}_{2} 0$, pH 5.6; D solution consisted of $1.0 \%(w / v)$, cellulase Onozuka R-10, 0.5\% (w/v) Driselase ${ }^{\circledR}$ (Duchefa Biochemie), $1.0 \%(w / v)$ macerozyme R-10, $0.6 \mathrm{M}$ mannitol, $20 \mathrm{mM}$ MES, $5.0 \mathrm{mM} \mathrm{MgCl} \mathrm{m}_{2} \cdot 6 \mathrm{H}_{2} 0$, pH 5.6. All enzyme solutions were filter-sterilized $(0.22 \mu \mathrm{m}$, Millipore, Durham, UK).

The isolated protoplasts were filtered through a $100 \mu \mathrm{m}$ nylon mesh (Millipore, Durham, UK) and centrifuged at $1,000 \mathrm{rpm}$ for $5 \mathrm{~min}$. Pellets were resuspended in $0.5 \mathrm{M}$ sucrose with $1 \mathrm{mM}$ MES, overlaid with $2 \mathrm{ml}$ of W5 salt solution (Menczel et al. 1981), and centrifuged for $10 \mathrm{~min}$ at $1,200 \mathrm{rpm}$. Protoplasts, now localized in the interphase between two solutions, were collected into a new tube with addition of W5 solution, and centrifuged at 1,000 rpm for $5 \mathrm{~min}$. The protoplast pellet was then resuspended in culture medium, and protoplast yield was counted using a hemocytometer. Density of cultured protoplasts was adjusted to $8 \times$ $10^{5}$ per milliliter of culture medium. The protocol of Damm and Willmitzer (1988) with modification of Grzebelus et al. (2012) for protoplast immobilization in a calcium alginate layer was employed. A suspension of protoplast and alginate solution consisting of $2.8 \%(w / v)$ Na-alginate and $0.4 \mathrm{M}$ mannitol was prepared by gentle mixing in equal volumes to obtain a final density of protoplasts in the culture of $4 \times 10^{5} \mathrm{ml}^{-1}$. Approximately $0.5 \mathrm{ml}$ of protoplast-alginate mixture was gently spread onto $1 \%(w / v)$ agar containing 
$20 \mathrm{mM} \mathrm{CaCl}{ }_{2}$. After $1 \mathrm{~h}$ incubation at room temperature, alginate disks with immobilized protoplasts were formed. The disks were transferred to the $6 \mathrm{~cm}$ Petri dish containing $4 \mathrm{ml}$ of culture medium.

Two types of culture medium were used: CPP medium according to Dirks et al. (1996) supplemented with $0.1 \mathrm{mg} \mathrm{l}^{-1}$ 2,4-dichlorophenoxyacetic acid $(2,4-\mathrm{D})$ and $0.2 \mathrm{mg} \mathrm{l}^{-1}$ zeatin, $\mathrm{pH} 5.6$; and $8 \mathrm{P}$ medium according to Glimelius (1984) supplemented with $1.0 \mathrm{mg} \mathrm{l}^{-1}$ 2,4-D, $0.1 \mathrm{mg} \mathrm{l}^{-1} 1$-naphthaleneacetic acid, and $0.5 \mathrm{mg} \mathrm{l}^{-1}$ benzyladenine, $\mathrm{pH}$ 5.6. Both media were filter sterilized $(0.22 \mu \mathrm{m}$; Millipore, Durham, UK). The cultivars were cultured on CPP medium exclusively, whereas DH lines on CPP and $8 \mathrm{P}$ medium. Culture media were renewed after $10 \mathrm{~d}$. Cultures were incubated in the dark at $26 \pm 2^{\circ} \mathrm{C}$.

Protoplast viability was estimated on the day of isolation $(0 \mathrm{~h})$, and at 24 and $48 \mathrm{~h}$ of culture, by staining with fluorescein diacetate according to Anthony et al. (1999). Metabolically active protoplasts were visualized by excitement of the accumulated fluorescein under blue light excitation at $485 \mathrm{~nm}$ with a $515 \mathrm{~nm}$ barrier filter, and observations were made using Axiovert S 100 (Carl Zeiss, Göttingen, Germany). Viable protoplasts exhibited yellow-green fluorescence, while nonviable protoplasts were invisible.

Plant regeneration. Colonies of protoplast-derived calli were freed from alginate layers according to the protocol of Damm and Willmitzer (1988). Callus colonies were transferred separately from each layer to $250 \mathrm{ml}$ jars containing regeneration media, of which three were used: MS medium consisting of MS micro- and macro-elements and vitamins with $20 \mathrm{gl}^{-1}$ sucrose, free of plant growth regulators (PGRs); R1-consisting of MS micro- and macroelements and vitamins with $0.4 \mathrm{mg}^{-1}$ calcium panthothenate, $0.1 \mathrm{mg} \mathrm{l}^{-1}$ gibberelic acid $\left(\mathrm{GA}_{3}\right), 3.0 \mathrm{mg} \mathrm{l}^{-1}$ kinetin, and $30 \mathrm{gl}^{-1}$ sucrose; R2 - consisting of MS micro- and macroelements, and modified vitamin composition; $0.5 \mathrm{mg} \mathrm{l}^{-1}$ nicotinic acid, $0.1 \mathrm{mg} \mathrm{l}^{-1}$ pyridoxine and thiamine, $3.0 \mathrm{mg} \mathrm{l}^{-1}$ glycine, and $20 \mathrm{gl}^{-1}$ sucrose. The media were adjusted to a $\mathrm{pH}$ of $5.7-5.8$ and $0.25 \%(w / v)$ Phytagel was added (Sigma) prior to autoclaving $\left(20 \mathrm{~min}\right.$ at $121^{\circ} \mathrm{C} ; 1.4 \times$ $10^{4} \mathrm{~kg} \mathrm{~m}^{-2}$ ). Developing shoots were transferred to fresh medium every $3-4 \mathrm{wk}$. Cultures were maintained at $26 \pm 2^{\circ} \mathrm{C}$ with $16 \mathrm{~h}$ photoperiod at a light intensity of $55 \mu \mathrm{mol} \mathrm{m} \mathrm{s}^{-1}$.

Statistical analysis. A single treatment consisted of five Petri dishes in three replicates. Each experiment was replicated three times. Protoplast yield was expressed as the number of protoplasts per gram of fresh weight (fw) of initial tissue. Viability of protoplasts was scored as number of protoplasts with green fluorescence per total number of observed cells $(\times 100)$. The means were calculated on the basis of a minimum of 200 cells per Petri dish. Division frequency of alginate-embedded protoplasts was expressed as the number of dividing protoplasts per total number of observed protoplasts $(\times 100)$, counted on days 5,10 , and 15 of culture. The regeneration frequency was calculated as the number of shoots regenerated from callus per total number of calli cultured on the regeneration medium $(\times 100)$. Analyses were performed using Statistica ver. 9.0 (Statsoft Poland Inc., Poland), using multivariate analysis of variance module. Mean separation was performed using Tukey's honestly significant difference.

\section{Results}

Yield of protoplasts. Protoplasts were successfully isolated from mesophyll tissue from all tested accessions. Protoplasts from white forms and Savoy cabbage were spherical and rich in chloroplasts that were randomly distributed in the cytosol. Protoplasts isolated from red forms (cv's. Rodeo F1, Reball F1, and DH lines) had bright green or purple interiors due to the presence of anthocyanins in the cell vacuoles. The yield of leaf protoplasts after isolation varied between tested accessions and was on average $2.0 \pm 0.1 \times 10^{6}$ per gram of fresh tissue (Table 1). The highest yields of leaf protoplast were noted for red forms of cabbage cv. Reball F1 and Rodeo F1 (being $3.2 \pm 0.2 \times 10^{6}$ and $2.6 \pm 0.4 \times 10^{6}$, respectively). Higher yields of protoplasts were obtained from leaves of 4- and 6-wk-old in vitro grown plants.

Mesophyll protoplasts were isolated from three doubled haploid lines using the same protocol as formerly described for cultivars, and in addition, three enzyme solutions and two culture media were used. Measurement of protoplasts was not performed in this study. However, based on the microscopic observations, protoplasts isolated from $\mathrm{DH}$ lines were smaller in comparison to mesophyll protoplasts isolated from tested cultivars. The yield of protoplasts from $1 \mathrm{~g}$ of fresh tissue of lines 582 and 5071 was similar to that obtained for cultivars Kamienna Głowa, Kilaxy F1, and Benia F1, and was on average $2.0 \times 10^{6}$ (Table 1). The lowest yield, at an average of $1.3 \pm 0.2 \times 10^{6} \mathrm{~g} \mathrm{fw}^{-1}$, was obtained for line 1071. The enzyme solution influenced the yield of protoplasts of tested DH lines. A larger number of protoplasts $\left(2.1 \pm 0.1 \times 10^{6} \mathrm{~g} \mathrm{fw}^{-1}\right)$ were isolated in the presence of ES enzyme solution. The lowest yield of protoplasts $\left(1.4 \pm 0.2 \times 10^{6} \mathrm{~g} \mathrm{fw}^{-1}\right)$ was obtained when digestion was performed using mixture containing $0.5 \%(w / v)$ Driselase $^{\circledR}$.

The hypocotyl-derived protoplasts were isolated from three selected B. oleracea cultivars, representing both white and red forms. The average yield of hypocotyl protoplasts was almost threefold lower $\left(0.7 \pm 0.1 \times 10^{6} \mathrm{~g} \mathrm{fw}^{-1}\right)$ than from mesophyll sources isolated from the same cultivars (Table 1). Differences in the yield of protoplasts were observed 
Table 1. Mean effect of accession, age of explant, and enzyme solution on the yield of protoplasts $\left(\times 10^{6} \mathrm{~g}^{-1} \mathrm{fw}\right)$ isolated from leaf mesophyll and hypocotyls of cultivars and DH lines of cabbage $( \pm \mathrm{SE})$

\begin{tabular}{|c|c|c|}
\hline \multirow[t]{2}{*}{ Factor } & \multicolumn{2}{|c|}{ Source of protoplasts } \\
\hline & Leaves & Hypocotyls \\
\hline \multicolumn{3}{|l|}{ Accession } \\
\hline Kamienna Głowa & $2.1 \pm 0.3 \mathrm{~b}, \mathrm{c}, \mathrm{d}$ & $0.7 \pm 0.1 \mathrm{a}, \mathrm{b}$ \\
\hline Amager & $1.4 \pm 0.3 \mathrm{c}, \mathrm{d}$ & $\mathrm{n} / \mathrm{a}$ \\
\hline Kilaxy F1 & $1.7 \pm 0.3 \mathrm{~b}, \mathrm{c}, \mathrm{d}$ & $0.6 \pm 0.1 \mathrm{~b}$ \\
\hline Benia F1 & $1.8 \pm 0.4 \mathrm{~b}, \mathrm{c}, \mathrm{d}$ & $\mathrm{n} / \mathrm{a}$ \\
\hline Rodeo F1 & $2.6 \pm 0.4 \mathrm{a}, \mathrm{b}$ & $\mathrm{n} / \mathrm{a}$ \\
\hline Reball F1 & $3.2 \pm 0.2 \mathrm{a}$ & $0.8 \pm 0.1 \mathrm{a}$ \\
\hline Vertus F1 & $2.3 \pm 0.4 \mathrm{~b}, \mathrm{c}$ & $\mathrm{n} / \mathrm{a}$ \\
\hline Line 582 & $1.9 \pm 0.2 \mathrm{~b}, \mathrm{c}, \mathrm{d}$ & $\mathrm{n} / \mathrm{a}$ \\
\hline Line 1071 & $1.3 \pm 0.2 \mathrm{~d}$ & $\mathrm{n} / \mathrm{a}$ \\
\hline Line 5071 & $2.0 \pm 0.1 \mathrm{~b}, \mathrm{c}, \mathrm{d}$ & $\mathrm{n} / \mathrm{a}$ \\
\hline \multicolumn{3}{|l|}{ Age of explant } \\
\hline 1 Week old & $\mathrm{n} / \mathrm{a}$ & $0.7 \pm 0.1 \mathrm{a}$ \\
\hline 2 Weeks old & $1.8 \pm 0.2 \mathrm{~b}$ & $0.7 \pm 0.1 \mathrm{a}$ \\
\hline 4 Weeks old & $2.1 \pm 0.1 \mathrm{a}$ & $\mathrm{n} / \mathrm{a}$ \\
\hline 6 Weeks old & $2.0 \pm 0.2 \mathrm{a}$ & $\mathrm{n} / \mathrm{a}$ \\
\hline Mean & $2.0 \pm 0.1$ & $0.7 \pm 0.1$ \\
\hline \multicolumn{3}{|l|}{ Enzyme solution $^{\mathrm{a}}$} \\
\hline $\mathrm{D}$ & $1.4 \pm 0.2 \mathrm{~b}$ & $\mathrm{n} / \mathrm{a}$ \\
\hline ES & $2.1 \pm 0.1 \mathrm{a}$ & $\mathrm{n} / \mathrm{a}$ \\
\hline ESIV & $1.8 \pm 0.1 \mathrm{a}, \mathrm{b}$ & $\mathrm{n} / \mathrm{a}$ \\
\hline
\end{tabular}

Values in each column followed by the same letter are not significantly different ( $p \leq 0.05$, Tukey's honestly significant difference)

${ }^{a}$ Applied only to DH lines, therefore excluded below mean

between tested cultivars. The highest yield $\left(0.8 \pm 0.1 \times 10^{6} \mathrm{~g}\right.$ $\mathrm{fw}^{-1}$ ) was obtained from red cabbage cv. Reball F1. No influence of the age of explant on the yield of hypocotylderived protoplasts was observed.

Viability of cabbage protoplasts immobilized in calcium alginate. On the day of isolation, viability of the leaf and hypocotyl protoplasts embedded in alginate was high, at an average of $85-90 \%$ for the cultivars (Fig. $1 A, B$ ) and $60-80 \%$ for the DH lines (Fig. $1 C-F$ ). The next day, however, a decrease of viability to about $5-8 \%$ was observed. There were no differences in viability of leaf-derived protoplast between tested accessions, but we observed differences determined by explant age. The highest viability, reaching about $90 \%$ on the day of isolation, was recorded for 4- and 6-wkold mesophyll (Fig. 1A)-derived protoplasts and 1-wkold hypocotyl (Fig. 1B)-derived protoplasts. The highest percent of viable protoplasts was noted from 6-wk-old DH line plantlets (Fig. 1D), when digestion was performed using ES enzyme solution (Fig. 1E) and when protoplasts were cultured on CPP medium (Fig. 1F).

Division frequency of cabbage protoplasts immobilized in calcium alginate. Around the third and fourth day of culture, protoplasts started to change shape and the first mitotic divisions were observed. On the fifth day, an average of 3.7 $\pm 0.4 \%$ cells isolated from leaves underwent the first division (Table 2). The division frequency increased with the duration of culture, and on the 15th day, reached an average of $9.9 \pm 1.0 \%$. Differences in ability to undergo divisions were identified, dependent on the accession. The highest percent $(29.8 \pm 2.2 \%)$ of dividing protoplasts was scored for cv. Reball F1 on day 15 of culture. Divisions in the range of $14-16 \%$ were observed for white form cultivars Kilaxy F1 and Kamienna Głowa. The mitotic activity of protoplasts isolated from $\mathrm{DH}$ lines was relatively low and varied from $1.1 \pm 0.5 \%$ (line 582 ) to $5.8 \pm 1.3 \%$ (line 5071 ), on the 15th day of culture. There were no differences in division frequency of protoplasts isolated from 4- and 6-wkold plantlets, and only $5.6 \pm 1.8 \%$ of protoplasts isolated from younger tissues underwent divisions after 2 wk of culture. The highest percent $(4.9 \pm 2.0 \%)$ of dividing protoplasts of tested DH lines was observed on CPP medium.

The division frequency of hypocotyl-derived protoplasts depended on the cultivar and the age of explants (Table 3), and interactions between these factors were observed. The highest percent $(17.5 \pm 0.3 \%)$ of dividing protoplasts was identified from 2-wk-old hypocotyls of cv. Reball F1, while for cv. Kamienna Głowa, superior results $(9.0 \pm 1.4 \%)$ were obtained from 1-wk-old explants.

Multiple cell colonies started to become visible to the naked eye at around the fourth wk of culture. Differences in the size of colonies were observed, caused by lack of synchrony in the mitotic divisions, consequently impacting colony development.

Plant regeneration. Colonies of calli were transferred to solid regeneration media. After approximately $4 \mathrm{wk}$, colonies started to differentiate, and formation of small green or purple-green shoots was observed. The regeneration ability was accession-dependent, and varied from 0.0 to $34.6 \pm$ $4.9 \%$ (Table 4). Colonies of calli from tested DH lines failed to regenerate. Calli tissue of cv. Amager only produced roots after transfer to the regeneration media, and no shoot regeneration was observed irrespective of the medium composition. The highest frequency of callus differentiation $(29.9 \pm$ $5.0 \%$ ) was recorded on the MS medium in the absence of PGRs. On this media, plantlets from six tested accessions (Kamienna Głowa, Kilaxy F1, Benia F1, Reball F1, Rodeo F1, and Savoy cabbage cv. Vertus F1) were regenerated. Shoot regeneration of cultivars Kamienna Głowa, Reball 

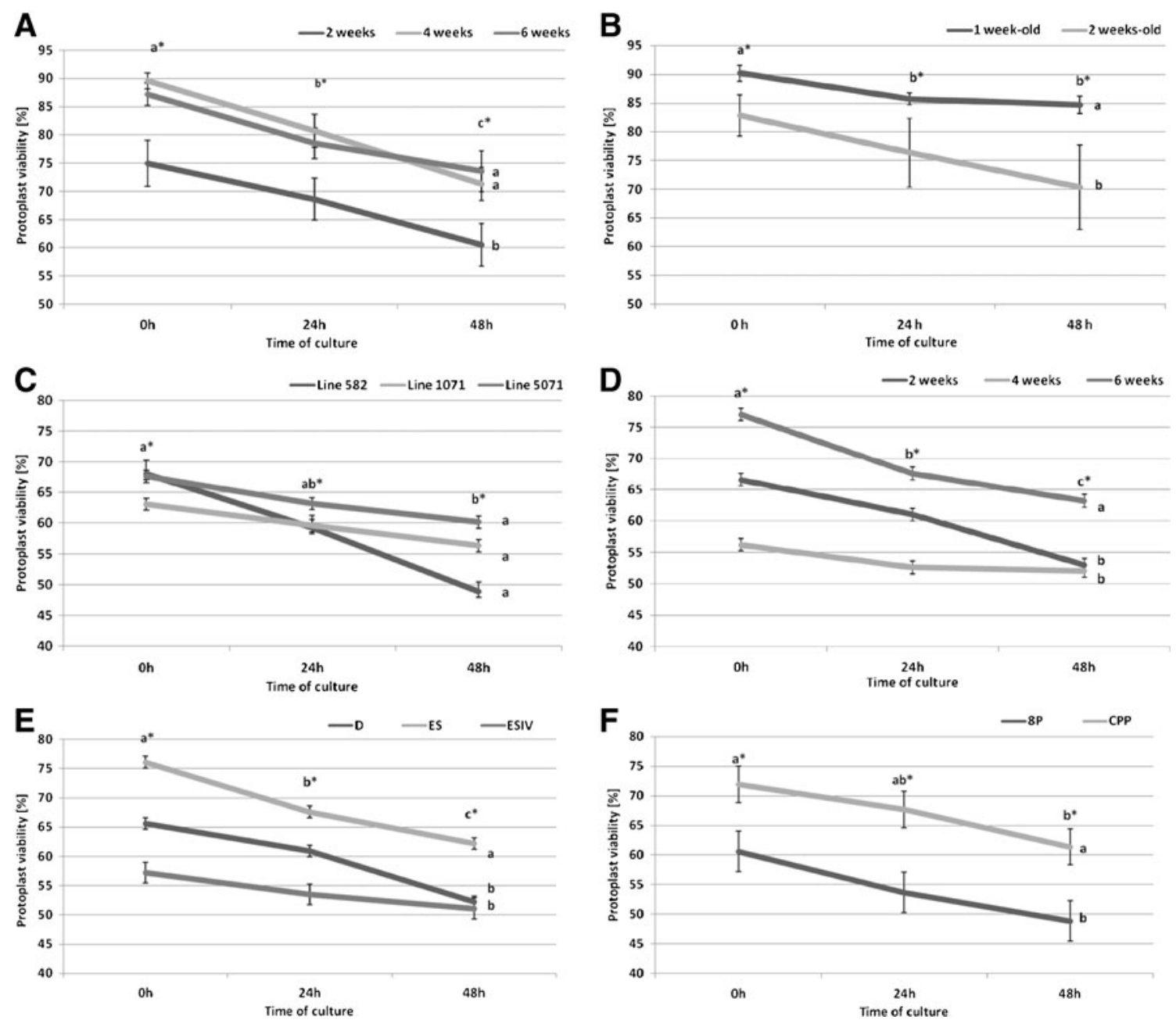

Figure 1. Protoplast viability. The effect of the age of the explant on viability of protoplasts isolated from leaf mesophyll $(A)$ and hypocotyls $(B)$ of tested cabbage cultivars $( \pm \mathrm{SE})$. The effect of the genotype $(C)$, age of explant $(D)$, enzyme solution $(E)$, and culture medium $(F)$ on the

F1, and Vertus F1 was recorded on the R1 medium, while on the R2 medium, only calli from cultivars Kamienna Głowa and Reball F1 were converted into plantlets. Differences in regeneration were dependent on the source of protoplasts. A higher percent $(26.2 \pm 4.2 \%)$ of regenerated shoots was observed from hypocotyl-derived protoplasts.

\section{Discussion}

Protoplasts from Brassica species were isolated from different sources, such as cell suspensions (Simmonds et al. 1991), leaves (Jourdan and Earle 1989), roots (Xu et al. 1982), petioles (Bornman 1985), cotyledons (Lu et al. 1982; Zhao et al. 1995), hypocotyls (Chuong et al. 1985), stem embryos (Kohlenbach et al. 1982), stem peels (Chuong et al. 1987), and stem cortex (Klimaszewska and Keller

viability of protoplast isolated from leaf mesophyll of DH lines of cabbage $( \pm \mathrm{SE})$. Values followed by the same letter are not significantly different $(p \leq 0.05, \mathrm{HSD})$. Letters with asterisks indicate significant differences in dependency on time of culture, remaining tested factor.

1987). The use of some types of tissues (such as roots and cortex) leads to a higher risk of contamination, while others (such as hypocotyls and cotyledons) required the use of large amount of seeds to obtain satisfactory yields, and others (such as suspension cultures) are difficult to maintain for Brassica species (Simmonds et al. 1991). In B. oleracea, protoplasts have previously been isolated mainly from leaves (Fu et al. 1985; Robertson and Earle 1986; Kaur et al. 2006) and hypocotyls (Glimelius 1984; Mukhopadhyay et al. 1991; Chen et al. 2004). In this study, both of these sources, taken from sterile conditions, were utilized and protoplasts were readily isolated for all tested accessions. The efficiency of isolation obtained was relatively high. The number of protoplasts released from leaf tissues was similar to the value reported for other Brassica species, for which yield was generally in the range of $1-4 \times 10^{6}$ per gram of fw (Robertson and Earle 1986; Davey et al. 2005b). The mean yield of hypocotyl-derived protoplasts reported for cabbage 
Table 2. Average effect of the accession, age of explants and culture medium on division frequency (\%) of protoplasts isolated from leaf mesophyll of cultivars and DH lines of cabbage $( \pm \mathrm{SE})$

\begin{tabular}{|c|c|c|c|}
\hline \multirow[t]{2}{*}{ Factor } & \multicolumn{3}{|l|}{ Time of culture } \\
\hline & 5 Days & 10 Days & 15 Days \\
\hline \multicolumn{4}{|l|}{ Accession } \\
\hline $\begin{array}{c}\text { Kamienna } \\
\text { Głowa }\end{array}$ & $6.5 \pm 0.9 \mathrm{a}$ & $10.2 \pm 1.1 \mathrm{a}, \mathrm{b}$ & $14.5 \pm 1.7 \mathrm{~b}$ \\
\hline Amager & $4.0 \pm 1.5 \mathrm{a}, \mathrm{b}, \mathrm{c}$ & $5.7 \pm 2.2 \mathrm{~b}, \mathrm{c}, \mathrm{d}$ & $8.3 \pm 2.7 \mathrm{~b}, \mathrm{c}, \mathrm{d}$ \\
\hline Kilaxy F1 & $4.9 \pm 0.6 \mathrm{a}, \mathrm{b}$ & $11.9 \pm 2.4 \mathrm{a}, \mathrm{b}$ & $16.8 \pm 4.0 \mathrm{~b}$ \\
\hline Benia F1 & $3.5 \pm 1.0 \mathrm{a}, \mathrm{b}, \mathrm{c}$ & $6.3 \pm 1.9 \mathrm{~b}, \mathrm{c}, \mathrm{d}$ & $9.2 \pm 2.5 \mathrm{~b}, \mathrm{c}, \mathrm{d}$ \\
\hline Rodeo F1 & $6.2 \pm 1.5 \mathrm{a}, \mathrm{b}$ & $9.3 \pm 2.3 \mathrm{a}, \mathrm{b}, \mathrm{c}$ & $13.3 \pm 3.5 \mathrm{~b}, \mathrm{c}$ \\
\hline Reball F1 & $7.8 \pm 2.0 \mathrm{a}$ & $15.3 \pm 2.8 \mathrm{a}$ & $29.8 \pm 2.2 \mathrm{a}$ \\
\hline Vertus F1 & $3.3 \pm 1.6 \mathrm{a}, \mathrm{b}, \mathrm{c}$ & $5.3 \pm 2.1 \mathrm{~b}, \mathrm{c}, \mathrm{d}$ & $7.0 \pm 2.6 \mathrm{~b}, \mathrm{c}, \mathrm{d}$ \\
\hline Line 582 & $0.2 \pm 0.1 \mathrm{c}$ & $0.5 \pm 0.2 \mathrm{~d}$ & $1.1 \pm 0.5 \mathrm{~d}$ \\
\hline Line 1071 & $1.2 \pm 0.4 \mathrm{~b}, \mathrm{c}$ & $1.8 \pm 0.5 \mathrm{c}, \mathrm{d}$ & $2.8 \pm 0.6 \mathrm{c}, \mathrm{d}$ \\
\hline Line 5071 & $2.1 \pm 0.5 \mathrm{~b}, \mathrm{c}$ & $3.8 \pm 0.8 \mathrm{c}, \mathrm{d}$ & $5.8 \pm 1.3 \mathrm{c}, \mathrm{d}$ \\
\hline \multicolumn{4}{|c|}{ Age of explant } \\
\hline $\begin{array}{l}2 \text { Weeks } \\
\text { old }\end{array}$ & $1.5 \pm 0.3 \mathrm{~b}$ & $3.2 \pm 1.0 \mathrm{~b}$ & $5.6 \pm 1.8 \mathrm{~b}$ \\
\hline $\begin{array}{l}4 \text { Weeks } \\
\text { old }\end{array}$ & $4.6 \pm 0.6 \mathrm{a}$ & $7.6 \pm 0.9 \mathrm{a}$ & $11.7 \pm 1.5 \mathrm{a}$ \\
\hline $\begin{array}{l}6 \text { Weeks } \\
\text { old }\end{array}$ & $4.3 \pm 0.7 \mathrm{a}$ & $8.0 \pm 1.3 \mathrm{a}$ & $11.2 \pm 2.0 \mathrm{a}$ \\
\hline Mean & $3.7 \pm 0.4 \mathrm{a}$ & $6.5 \pm 0.7 \mathrm{~b}$ & $9.9 \pm 1.0 \mathrm{c}$ \\
\hline \multicolumn{4}{|c|}{ Culture medium $^{\mathrm{a}}$} \\
\hline $8 \mathrm{P}$ & $0.6 \pm 0.4 \mathrm{~b}$ & $1.1 \pm 0.7 \mathrm{~b}$ & $1.6 \pm 0.8 \mathrm{~b}$ \\
\hline СРP & $1.7 \pm 0.9 \mathrm{a}$ & $3.1 \pm 1.3 \mathrm{a}$ & $4.9 \pm 2.0 \mathrm{a}$ \\
\hline
\end{tabular}

Values in each column followed by the same letter are not significantly different ( $p \leq 0.05$, Tukey's honestly significant difference)

${ }^{a}$ Applied only to DH lines, therefore excluded below mean

is on average $1-3.5 \times 10^{5}$ per gram of tissue (Glimelius 1984; Chen et al. 2004). Using the present protocol, higher

Table 3. Interaction of cultivar and age of explants on the division frequency $(\%)$ of protoplast isolated from hypocotyls of selected cultivars of cabbage $( \pm \mathrm{SE})$

\begin{tabular}{lllll}
\hline $\begin{array}{l}\text { Explant } \\
\text { age }\end{array}$ & Cultivar & \multicolumn{4}{l}{ Time of culture } \\
\cline { 3 - 5 } & & \multicolumn{1}{l}{5 Days } & 10 Days & 15 Days \\
\hline 1 Week & Kamienna & $2.5 \pm 0.7 \mathrm{a}$ & $4.5 \pm 0.7 \mathrm{~b}$ & $9.0 \pm 1.4 \mathrm{~b}$ \\
old & Głowa & & & \\
& Kilaxy F1 & $4.5 \pm 0.5 \mathrm{a}$ & $6.0 \pm 1.0 \mathrm{~b}$ & $7.5 \pm 2.0 \mathrm{~b}, \mathrm{c}$ \\
& Reball F1 & $2.5 \pm 0.7 \mathrm{a}$ & $5.5 \pm 0.2 \mathrm{~b}$ & $8.0 \pm 1.4 \mathrm{~b}, \mathrm{c}$ \\
2 Weeks & Kamienna & $3.0 \pm 0.8 \mathrm{a}$ & $4.0 \pm 2.1 \mathrm{~b}$ & $5.0 \pm 2.1 \mathrm{~b}, \mathrm{c}$ \\
old & Głowa & & & \\
& Kilaxy F1 & $1.5 \pm 0.4 \mathrm{a}$ & $3.0 \pm 0.0 \mathrm{~b}$ & $3.0 \pm 0.0 \mathrm{c}$ \\
& Reball F1 & $6.0 \pm 0.7 \mathrm{a}$ & $10.5 \pm 1.4 \mathrm{a}$ & $17.5 \pm 0.3 \mathrm{a}$ \\
Mean & & $3.3 \pm 0.6 \mathrm{c}$ & $5.6 \pm 0.9 \mathrm{~b}$ & $8.3 \pm 1.2 \mathrm{a}$ \\
\hline
\end{tabular}

Values in each column followed by the same letter are not significantly different ( $p \leq 0.05$, Tukey's honestly significant difference)
Table 4. Effect of source tissue, accession, and media on the efficiency $(\%)$ of shoot regeneration from the protoplast-derived callus colonies of different cabbage accessions $( \pm \mathrm{SE})$

\begin{tabular}{llll}
\hline \multirow{4}{*}{ Factor } & \multicolumn{3}{l}{ Source of protoplasts } \\
\cline { 2 - 4 } & Leaves & Hyopcotyls & Mean \\
\hline Accession & & & \\
Kamienna & $36.8 \pm 5.8 \mathrm{a}, \mathrm{b}$ & $22.8 \pm 5.1 \mathrm{a}$ & $29.8 \pm 5.5 \mathrm{a}, \mathrm{b}$ \\
$\quad$ Głowa & & & \\
Amager & $0.0 \mathrm{~d}$ & $\mathrm{n} / \mathrm{a}$ & $0.0 \mathrm{e}$ \\
Kilaxy F1 & $24.5 \pm 3.5 \mathrm{a}, \mathrm{b}, \mathrm{c}$ & $28.1 \pm 4.2 \mathrm{a}$ & $26.4 \pm 3.9 \mathrm{a}, \mathrm{b}, \mathrm{c}$ \\
Benia F1 & $16.4 \pm 1.9 \mathrm{c}, \mathrm{d}$ & $\mathrm{n} / \mathrm{a}$ & $16.4 \pm 1.9 \mathrm{c}, \mathrm{d}$ \\
Rodeo F1 & $11.4 \pm 1.6 \mathrm{c}, \mathrm{d}$ & $\mathrm{n} / \mathrm{a}$ & $11.4 \pm 1.6 \mathrm{~d}$ \\
Reball F1 & $41.6 \pm 6.5 \mathrm{a}$ & $27.6 \pm 3.3 \mathrm{a}$ & $34.6 \pm 4.9 \mathrm{a}$ \\
Vertus F1 & $22.2 \pm 3.4 \mathrm{~b}, \mathrm{c}$ & $\mathrm{n} / \mathrm{a}$ & $22.2 \pm 3.4 \mathrm{~b}, \mathrm{c}, \mathrm{d}$ \\
Line 582 & $0.0 \mathrm{~d}$ & $\mathrm{n} / \mathrm{a}$ & $0.0 \mathrm{e}$ \\
Line 1071 & $0.0 \mathrm{~d}$ & $\mathrm{n} / \mathrm{a}$ & $0.0 \mathrm{e}$ \\
Line 5071 & $0.0 \mathrm{~d}$ & $\mathrm{n} / \mathrm{a}$ & $0.0 \mathrm{e}$ \\
Regeneration medium & & \\
MS & $19.8 \pm 5.1 \mathrm{a}$ & $40.0 \pm 4.8 \mathrm{a}$ & $29.9 \pm 5.0 \mathrm{a}$ \\
R1 & $15.6 \pm 3.6 \mathrm{a}, \mathrm{b}$ & $25.7 \pm 3.0 \mathrm{~b}$ & $20.7 \pm 3.3 \mathrm{~b}$ \\
R2 & $10.6 \pm 2.7 \mathrm{~b}$ & $13.0 \pm 4.7 \mathrm{c}$ & $11.8 \pm 3.7 \mathrm{c}$ \\
Mean & $15.3 \pm 3.8 \mathrm{~b}$ & $26.2 \pm 4.2 \mathrm{a}$ & \\
\hline
\end{tabular}

Values in each column followed by the same letter are not significantly different ( $p \leq 0.05$, Tukey's honestly significant difference)

yields $\left(0.7 \pm 0.1 \times 10^{6}\right)$ of protoplasts were obtained from the same amount of tissue.

The DH lines of cabbage used in this study exhibited lower seed vigor and differing performance (smaller and more compact leaf, less roots) than for tested cultivars. The yield as well as protoplast viability of tested DH lines was also reduced in comparison to the cultivars. Enzymatic solutions containing cellulase, pectolyase, macerozyme, and Driselase $^{\circledR}$ were used in this experiment. The first three enzymes are typically used for tissue digestion in Brassica sp. protoplast isolation protocols, but Driselase ${ }^{\circledR}$ has been used sporadically. Robertson and Earle (1986) reported that use of an enzymatic solution containing $0.5 \%(w / v)$ Driselase ${ }^{\circledR}$ for broccoli protoplasts isolation increased the yield, but this observation was not confirmed in our study. Protoplasts from DH lines were cultured on two media. The frequencies of divisions obtained on CPP medium were higher than those on $8 \mathrm{P}$, possibly due to the presence of lower $\left(0.1 \mathrm{mg} \mathrm{l}^{-1}\right)$ concentration of 2,4-D. The beneficial influence of different levels of 2,4-D in the culture medium was reported for Brassica sp. (Kohlenbach et al. 1982; Glimelius 1984). However, our results suggest that lower concentrations were more beneficial for stimulation of cell divisions for tested DH lines. Relatively good yields of viable protoplasts were obtained, but despite testing various culture conditions, it was difficult to obtain protoplasts 
which underwent divisions at high frequencies from tested DH lines.

Young tissues from in vitro conditions generally obtained optimal results from Brassica sp. However, successful protoplast culture and plantlet regeneration from greenhousegrown plants has been also reported (Shillito et al. 1983; Fu et al. 1985). In general, to obtain optimal amount and quality of tissue from in vitro sown seeds, a period of 1 mo is required. Such plantlets are young, vigorous and healthy, and therefore the best source of material for culture. In the present study, the highest yield of viable protoplasts undergoing divisions was obtained from the leaf tissue of 4to 6-wk-old plantlets. Higher proportions of viable hypocotyl-derived protoplasts were observed from 1-wkold explants, but the division frequency of such protoplasts was both age- and accession-dependent. The use of younger hypocotyls was also reported, but sowing of more seeds is required to obtain sufficient yields (Glimelius 1984; Mukhopadhyay et al. 1991; Chen et al. 2004), and division frequency may be lowered (Fu et al. 1985; Robertson et al. 1988).

Some studies suggest that with higher culture densities, higher plating efficiencies could be achieved (Chuong et al. 1985; Vamling and Glimelius 1990). Cultured protoplasts stimulate mitotic division of adjacent cells by releasing growth factors, including amino acids, into the surrounding medium (Davey et al. 2005a). The optimum plating density for $B$. oleracea is usually $5 \times 10^{4}$ protoplasts per milliliter of culture medium (Pelletier et al. 1983; Glimelius 1984; Robertson and Earle 1986). In this study, a higher culture density $\left(4 \times 10^{5} \mathrm{ml}^{-1}\right)$ was applied. The high density of the culture may be responsible for decreasing viability of protoplasts as observed in our study. Considering the frequencies of divisions that were obtained, it seems likely that denser cultures rapidly depleted available nutrients and a large number of protoplasts failed to undergo divisions.

The timing of the first mitotic division is generally expected between 24 and $48 \mathrm{~h}$ of culture (Glimelius 1984; Mukhopadhyay et al. 1991), but a shift of the first mitosis to days 3 or 4 of culture, as observed in our study, was also reported for B. oleracea (Fu et al. 1985; Robertson and Earle 1986; Kaur et al. 2006). Division frequencies in $B$. oleracea varied as a consequence of the source of tissue, culture system, culture maintenance, and genotype. The average division frequency reported for Brassica spp. in the vicinity of second week of culture varied from $0 \%$ to 40\% (Glimelius 1984; Zhao et al. 1995; Chen et al. 2004). Colony formation is usually established after $20-30 \mathrm{~d}$. The size of colonies at the time of transfer is important and not dependent on the protoplast source. Callus colonies that are too small $(<2 \mathrm{~mm})$ generally do not differentiate, and eventually become brown and die. In contrast, larger colonies are able to form shoot primordia, and regeneration of plants from such colonies is much more effective (Glimelius 1984; Fu et al. 1985; Kaur et al. 2006).

Brassica protoplast cultures are usually maintained in liquid media, requiring three to four medium replacements during the culture period (Pelletier et al. 1983; Glimelius 1984; Robertson and Earle 1986; Mukhopadhyay et al. 1991). Studies revealed that in the liquid culture, protoplasts tend to aggregate and release brown particles (phenolic compounds) into the medium; moreover, the aggregates tend to fall to the bottom of the Petri dish, consequently decreasing protoplast divisions and causing death (Klimaszewska and Keller 1987; Mukhopadhyay et al. 1991; Kaur et al. 2006). To prevent aggregation, browning, and necrosis in the culture, and to improve plating efficiency, various protoplast culture systems were applied. The use of agarose (Yamashita and Shimamoto 1989), combining liquid and solidified (agarose) phases (Klimaszewska and Keller 1987), as well as use of feeder layers (Walters and Earle 1990) and nurse cultures (Chen et al. 2001) has been reported. Agarose has assisted prevention of aggregation and necrosis of $B$. juncea protoplasts, but has no beneficial effect on protoplasts of B. oleracea (Chen et al. 2004). Immobilization in alginate was used for species such as Arabidopsis thaliana, for which frequency of divisions ranged from $0.6 \%$ to 30\% (Damm and Willmitzer 1988; Dovzhenko et al. 2003), sugar beet (20-30\%; Hall et al. 1993), carrot (4-70\%; Dirks et al. 1996; Grzebelus et al. 2012), and tobacco (96\%; Dovzhenko et al. 1998). Our study suggests that the use of alginate layers has a positive effect on cultured protoplasts, with mitotic divisions being noted for all tested accessions. However, a strong effect of genotype was observed for each of the important steps of the experiment (mitotic divisions, shoot regeneration), which determined the final results. In B. oleracea, many authors have emphasized the importance of genetic control in the ability to regenerate from protoplastderived microcalli.

A genetic study indicated that the regeneration ability is controlled by two or three genes (Hansen et al. 1999b). Further studies verified the general hypothesis, reducing the number of controlling genes to two, and eliminating major dominance effects (Holme et al. 2004). Such results demonstrate that success in protoplast cultures depends on possession of genotypic constitutions with major highresponse genes in available materials or introgression of these genes to recalcitrant lines (Armstrong et al. 1992; Koorneef et al. 1993; Holme et al. 2004). Average regeneration frequencies reported for Brassica spp. are between $0 \%$ and 55\% from mesophyll protoplasts and $0-30 \%$ from hypocotyls (Glimelius 1984; Jourdan and Earle 1989; Yamashita and Shimamoto 1989; Hu et al. 1990; Ren et al. 2000; Kirti et al. 2001), but higher frequencies (80-90\%) have been also reported (Mukhopadhyay et al. 1991; Delpierre and Boccon-Gibod 1992). In the present study, 
all regenerated plants were normal, well-developed and healthy, without variegation. The highest regeneration frequency was obtained on the MS hormone-free medium. Addition of $\mathrm{GA}_{3}$ and kinetin (R1) as well as modification of MS medium vitamin composition (R2) did not significantly enhance regeneration. The observed higher regeneration frequency of hypocotyl-derived protoplasts may be explained by exclusive use of the best-responding genotypes, while leaf protoplasts were isolated from wide range of genotypes with different responses to the applied culture conditions.

\section{Conclusions}

Differentiation in the in vitro cultures is generally known to be genotype-specific, and Brassica species are no exception (Jourdan and Earle 1989; Loudon et al. 1989; Zhao et al. 1995; Hansen et al. 1999a), as confirmed in this study. Mesophyll- and hypocotyl-derived protoplasts were successfully isolated with satisfactory yields, viability, and division frequencies, especially for the red form of cabbage cv. Reball F1 and white form of cabbage cv. Kamienna Głowa, enabling use in further research. The modification of culture maintenance such as immobilization of protoplasts in extra thin alginate films (Pati et al. 2005) may be beneficial, and will be performed in the future. Further efforts to transfer resistance genes by protoplast fusion will be continued in our laboratory.

Open Access This article is distributed under the terms of the Creative Commons Attribution License which permits any use, distribution, and reproduction in any medium, provided the original author(s) and the source are credited.

\section{References}

Anthony P, Otoni W, Power JB, Lowe KC, Davey MR (1999) Protoplast isolation culture, and plant regeneration from Passiflora. In: Hall RD (ed) Methods in molecular biology_plant cell culture protocols, vol 111. Humana Press, Totowa, USA, pp 169-179

Armstrong CL, Romero-Severson J, Hodges TK (1992) Improved tissue culture response of an elite maize inbred through backcross breeding, and identification of chromosomal regions important for regeneration by RFLP analysis. Theor Appl Genet 84:755-762

Bornman CH (1985) Regeneration in vitro of economically important crop plants in the Nordic countries. Hereditas 103:7-13

Chen L-P, Zhang M-F, Hirata Y, Cao JS, Chen ZJ (2001) Efficient plant regeneration from cotyledon-derived protoplasts of cytoplasmic male-sterile tuber mustard (B. juncea Coss. var. Tumida Tsen et Lee). Acta Phytophysiol Sin 5:437-440

Chen L-P, Zhang M-F, Xiao Q-B, Wu J-G, Hirata Y (2004) Plant regeneration from hypocotyl protoplasts of red cabbage (Brassica oleracea) by using nurse cultures. Plant Cell Tissue Organ Cult 77:133-138

Chuong PV, Beversdorf WD, Pauls KP (1987) Plant regeneration from haploid stem peel protoplasts of Brassica napus L. J Plant Physiol 130:57-65

Chuong PV, Pauls KP, Beversdorf WD (1985) A simple culture method for Brassica hypocotyl protoplasts. Plant Cell Rep 4:4-6

Damm B, Willmitzer L (1988) Regeneration of fertile plants from protoplasts of different Arabidopsis thaliana genotypes. Mol Gen Genet 213:15-20

Davey MR, Anthony P, Power JB, Lowe KC (2005a) Plant protoplasts: status and biotechnological perspectives. Biotechnol Adv 23:131171

Davey MR, Anthony P, Power JB, Lowe KC (2005b) Plant protoplast technology: current status. Acta Physiol Plant 27:117-129

Delpierre N, Boccon-Gibod J (1992) An extensive hairy root production precedes shoot regeneration in protoplast-derived calli of cauliflower (Brassica oleracea var. botrytis). Plant Cell Rep 11:351-354

Dirks R, Sidorov V, Tulmans C (1996) A new protoplast culture in Daucus carota L. and its applications for mutant selection and transformation. Theor Appl Genet 93:809-815

Dovzhenko A (2001) Towards plastid transformation in rapeseed (Brassica napus L.) and sugarbeet (Beta vulgaris L.). Dissertation, LMU München: Fakultät für Biologie. http://edoc.ub. uni-muenchen.de/34/. Cited 8th August 2011

Dovzhenko A, Bergen U, Koop HU (1998) Thin-alginate-layer technique for protoplast culture of tobacco leaf protoplasts: shoot formation in less than two weeks. Protoplasma 204:114-118

Dovzhenko A, Dal Bosco C, Meurer J, Koop HU (2003) Efficient regeneration from cotyledon protoplasts in Arabidopsis thaliana. Protoplasma 222:107-111

Fahleson J, Eriksson I, Landgren M, Stymne S, Glimelius K (1994) Intertribal somatic hybrids between Brassica napus and Thlaspi perfoliatum with high content of the $T$. perfoliatum-specific nervonic acid. Theor Appl Genet 87:795-804

Fu Y-Y, Jia S-R, Lin Y (1985) Plant regeneration from mesophyll protoplast culture of cabbage (Brassica oleracea var 'capitata'). Theor Appl Genet 71:495-499

Glimelius K (1984) High growth rate and regeneration capacity of hypocotyl protoplasts in some Brassicaceae. Physiol Plant 61:38-44

Grzebelus E, Szklarczyk M, Barański R (2012) An improved protocol for plant regeneration from leaf- and hypocotyl-derived protoplasts of carrot. Plant Cell Tissue Organ Cult. doi:10.1007/ s11240-011-0078-5

Hall RD, Pedersen C, Krens FA (1993) Improvement of protoplast culture protocols for Beta vulgaris L. (sugar beet). Plant Cell Rep 12:339-342

Hansen LN, Earle ED (1994) Novel flowering and fatty acid characters in rapid cycling Brassica napus L. resynthesized by protoplast fusion. Plant Cell Rep 14:151-156

Hansen LN, Earle ED (1995) Transfer of resistance to Xanthomonas campestris pv. campestris into Brassica oleracea L. by protoplast fusion. Theor Appl Genet 91:1293-1300

Hansen LN, Earle ED (1997) Somatic hybrids between Brassica oleracea L. and Sinapsis alba L. with resistance to Alternaria brassicae (Berk.) Sacc. Theor Appl Genet 94:1078-1085

Hansen LN, Ortiz R, Andersen SB (1999a) Genetic analysis of protoplast regeneration ability in Brassica oleracea. Plant Cell Tissue Organ Cult 58:127-132

Hansen LN, Rodomiro O, Andersen SB (1999b) Genetic analysis of protoplast regeneration ability in Brassica oleracea. Plant Cell Tissue Organ Cult 58:127-132

Heath DW, Earle ED (1997) Synthesis of low linolenic acid rapeseed (Brassica napus L.) through protoplast fusion. Euphytica 93:339343 
Holme IB, Torp AM, Hansen LN, Andersen SB (2004) Quantitative trait loci affecting plant regeneration from protoplasts of Brassica oleracea. Theor Appl Genet 108:1513-1520

Hu Q, Andersen SB, Hansen LN (1990) Plant regeneration capacity of mesophyll protoplasts from Brassica napus and related species. Plant Cell Tissue Org Cult 59:189-196

Jourdan PS, Earle ED (1989) Genotypic variability in the frequency of plant regeneration from leaf protoplasts of four Brassica spp. and of Raphanus sativus. J Am Soc Hortic Sci 114:343-349

Kao KN, Michayluk MR (1975) Nutritional requirements for growth of Vicia hajastana cells and protoplasts at a very low population density in liquid media. Planta 126:105-110

Kaur ND, Vyvadilová M, Klíma M, Bechyně M (2006) A simple procedure for mesophyll protoplast culture and plant regeneration in Brassica oleracea L. and Brassica napus L. Czech J Genet Plant Breed 42:103-110

Kirti PB, Bhat SR, Kumar VD, Parkash S, Chopra VL (2001) A simple protocol for regenerating mesophyll protoplasts of vegetable Brassicas. J Plant Biochem Biotechnol 10:49-51

Klimaszewska K, Keller WA (1987) Plant regeneration from stem cortex protoplasts of Brassica napus. Plant Cell Tissue Organ Cult 8:225-233

Kohlenbach HW, Wenzel G, Hoffmann F (1982) Regeneration of Brassica napus plantlets in cultures from isolated protoplasts of haploid stem embryos as compared with leaf protoplasts. Z Pflanzenphysiol 105:131-142

Koorneef M, Bade J, Hanhart C, Horsman K, Schel J, Soppe W, Verkerk R, Zabel P (1993) Characterization and mapping of a gene controlling shoot regeneration in tomato. Plant J 3:131-141

Loudon PT, Nelson RS, Ingram DS (1989) Studies of protoplast culture and plant regeneration from commercial and rapid cycling Brassica species. Plant Cell Tissue Organ Cult 19:213-224

Lu DY, Pental D, Cocking EC (1982) Plant regeneration from seedling cotyledon protoplasts. Z Pflanzenphysiol 107:59-63

Menczel L, Nagy F, Kiss ZsR Maliga P (1981) Streptomycin resistant and sensitive hybrids of Nicotiana tabacum +Nicotiana knightiana: correlation of resistance to N. tabacum plastids. Theor Appl Genet 59:191-195

Mukhopadhyay A, Töpfer R, Pradhan AK, Sodhi YS, Steinbiß HH, Schell J, Pental D (1991) Efficient regeneration of Brassica oleracea hypocotyl protoplasts and high frequency genetic transformation by direct DNA uptake. Plant Cell Rep 10:375-379

Murashige T, Skoog F (1962) A revised medium for rapid growth and bioassays with tobacco tissue cultures. Physiol Plant 15: 473-497

Pati PK, Sharma M, Ahuja PS (2005) Extra thin alginate film: an efficient technique for protoplast culture. Protoplasma 226:217-221

Pelletier G, Primard C, Vedel F, Chetrit P, Remy R, Rouselle P, Renard M (1983) Intergeneric cytoplasmic hybridization in Cruciferae by protoplast fusion. Mol Gen Genet 191:244-250

Radchuk VV, Ryschka U, Schumann G, Klocke E (2002) Genetic transformation of cauliflower (Brassica oleracea var. botrytis) by direct DNA uptake into mesophyll protoplasts. Physiol Plant 114:429-438

Ren JP, Dickson MH, Earle ED (2000) Improved resistance to bacterial soft rot by protoplast fusion between Brassica rapa and B. oleracea. Theor Appl Genet 100:810-819

Robertson D, Earle ED (1986) Plant regeneration from leaf protoplasts of Brassica oleracea var. italica CV 'Green Comet broccoli'. Plant Cell Rep 5:61-64

Robertson D, Earle ED, Mutschler MA (1988) Increased totipotency of protoplasts from Brassica oleracea plants previously regenerated in tissue culture. Plant Cell Tissue Organ Cult 14:15-24

Shillito RD, Paszkowski J, Potrykus I (1983) Agarose plating and a bead type culture technique enable and stimulate development of protoplast-derived colonies in a number of plant species. Plant Cell Rep 2:244-247

Sigareva MA, Earle ED (1997) Direct transfer of a cold-tolerant Ogura male-sterile cytoplasm into cabbage (Brassica oleracea ssp. capitata) via protoplast fusion. Theor Appl Genet 94:213-220

Sigareva MA, Earle ED (1999) Regeneration of plants from protoplasts of Capsella bursa pastoris and somatic hybridization with rapidcycling Brassica oleracea. Plant Cell Rep 18:412-417

Simmonds DH, Long NE, Keller WA (1991) High plating efficiency and plant regeneration frequency in low density protoplast cultures derived from an embryogenic Brassica napus cell suspension. Plant Cell Tissue Organ Cult 27:231-241

Vamling K, Glimelius K (1990) Regeneration of plants from protoplasts of oilseed Brassica crops. In: Bajaj YPS (ed) Biotechnology in agriculture and forestry, vol 10. Springer, Heidelberg, pp 385-417

Walters TW, Earle ED (1990) A simple, versatile feeder layer system for Brassica oleracea protoplast culture. Plant Cell Rep 9:316-319

Wang YP, Sonntag K, Rudloff E (2003) Development of rapeseed with high erucic acid content by asymmetric somatic hybridization between Brassica napus and Crambe abysinica. Theor Appl Genet 106:1147-1155

Xu ZH, Davey MR, Cocking EC (1982) Plant regeneration from root protoplasts of Brassica. Plant Sci Lett 24:117-121

Yamagishi H, Landgren M, Forsberg J, Glimelius K (2002) Production of asymmetric hybrids between Arabidopsis thaliana and Brassica napus utilizing an efficient protoplast culture system. Theor Appl Genet 104:959-964

Yamashita Y, Shimamoto K (1989) Regeneration of plants from cabbage (Brassica oleracea var. capitata) protoplasts. In: Bajaj YPS (ed) Biotechnology in agriculture and forestry Vol 8. Springer, Berlin, pp 193-205

Yarrow SA, Burnett LA, Wilderman RP, Kemble RJ (1990) The transfer of 'Polima' cytoplasmic male sterility from oilseed rape (Brassica napus) to broccoli (B. oleracea) by protoplast fusion. Plant Cell Rep 9:185-188

Zhao K-N, Bittisnich DJ, Halloran GM, Whitecross MI (1995) Studies of cotyledon protoplast cultures from B. napus, B. campestris and $B$. oleracea. II: Callus formation and plant regeneration. Plant Cell Tissue Organ Cult 40:73-84 